\title{
Genetic parameter estimation for major milk fatty acids in Alpine and Saanen primiparous goats
}

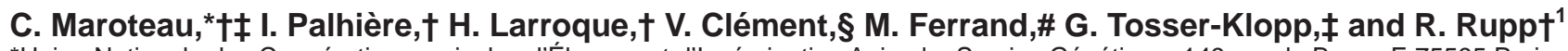 \\ *Union Nationale des Coopératives agricoles d'Élevage et d'Insémination Animale, Service Génétique, 149 rue de Bercy, F-75595 Paris, France \\ †INRA, UMR1388 Génétique, Physiologie et Systèmes d'Élevage, F-31326 Castanet-Tolosan, France \\ łINRA, UMR444 Génétique Cellulaire, F-31326 Castanet-Tolosan, France \\ §Institut de l'Élevage, F-31326 Castanet-Tolosan, France \\ \#Institut de l'Élevage, F-75595 Paris, France
}

\section{ABSTRACT}

Genetic parameters for 18 fatty acids or groups of fatty acids (FA), milk production traits, and somatic cell score (SCS) were estimated by restricted maximum likelihood with a repeatability animal model, using 45,259 test-day records from the first lactations of 13,677 Alpine and Saanen goats. Fatty acid data were collected as part of an extensive recording scheme (PhénoFinLait), and sample testing was based on mid-infrared spectra estimates. The total predicted FA content in milk was approximately $3.5 \%$ in Alpine and Saanen goats. Goat milk fat showed similar saturated FA to cattle and sheep, but higher contents of capric (C10:0) FA $(\sim 9.7 \mathrm{~g} / 100 \mathrm{~g}$ of milk fat). Heritability estimates ranged from 0.18 to 0.49 for $\mathrm{FA}$ and estimates were generally higher when FA were expressed in $\mathrm{g} / 100 \mathrm{~g}$ of milk fat compared with $\mathrm{g} / 100 \mathrm{~g}$ of milk. In general, the 3 specific short- and medium-chain goat FA, caproic acid (C6:0), caprylic acid (C8:0), and especially capric (C10:0) acid, had among the highest heritability estimates (from 0.21 to 0.37 ; average of 0.30 ). Heritability estimates for milk yield, fat and protein contents, and SCS were $0.22,0.23,0.39,0.09$, and $0.24,0.20,0.40$, and 0.15, in Alpine and Saanen goats, respectively. When FA were expressed in $\mathrm{g} / 100 \mathrm{~g}$ of milk, genetic correlations between fat content and all FA were high and positive. Genetic correlations between the fat content and FA groups expressed in $\mathrm{g} / 100 \mathrm{~g}$ of fat led to further investigation of the association between fat content and FA profile within milk fat. Accordingly, in both Saanen and Alpine breeds, no significant genetic correlations were found between fat content and C16:0, whereas the correlations between fat content and specific goat FA (C6:0 to $\mathrm{C} 10: 0)$ were positive (0.17 to 0.59$)$. In addition, the genetic correlation between fat content and C14:0 was negative $(-0.17$ to -0.35$)$. The values of the

Received August 1, 2013.

Accepted January 2, 2014.

${ }^{1}$ Corresponding author: rachel.rupp@toulouse.inra.fr genetic correlations between protein content and individual FA were similar, although genetic correlations between protein content and FA groups were close to zero. Genetic correlations of milk yield or SCS with the FA profile were weak. Results for genetic parameters for FA, however, should be further validated, because the low predicting ability of certain FA using mid-infrared spectra and the limited calibration data set might have resulted in low accuracy. In conclusion, our results indicated substantial genetic variation in goat milk FA that supported their amenability for genetic selection. In addition, selection on protein and fat contents is not expected to have an undesirable effect on the FA profile in regard to specificity of goat products and human health.

Key words: fatty acid, dairy goat, milk composition, genetic parameters

\section{INTRODUCTION}

Total worldwide goat milk production was 51,235 million tonnes in 2008. About 5\% of this production was from European countries and France is the leading goat milk producer in Europe, with production of 584,000 t of milk in 2009 (Institut de l'Élevage, 2010). In France, goat milk is mainly used for commercial and farmhouse cheeses, with a production of about 109,900 $\mathrm{t}$ and an average consumption of about $2 \mathrm{~kg}$ per person and year in 2009 (Institut de l'Élevage, 2010).

Goat milk fat represents approximately $4 \%$ of the total milk constituents. Goat and cow milks have similar FA composition, although some specific short- and medium-chain FA - caproic acid (C6:0), caprylic acid (C8:0), and capric acid (C10:0) - are more abundant in goats; they form 15 to $18 \%$ (compared with up to $10 \%$ in cow milk) of the total FA (Chilliard et al., 2006; Raynal-Ljutovac et al., 2008).

Fatty acids are well known for their importance in human nutrition. Numerous studies, reviewed in Arnould and Soyeurt (2009), have reported that SFA, and especially lauric (C12:0), myristic (C14:0), and palmitic acids (C16:0), have an unfavorable relation 
with some heart diseases, diabetes, and obesity (Mensink et al., 2003; Haug et al., 2007). In contrast, unsaturated fatty acids (UFA), usually called "healthy" fatty acids, are reported to have a favorable effect on health, especially on cholesterol levels. However, some short- and medium-chain SFA, such as C6:0 to C10:0, which are well known for their role in the specific goat flavor (C8:0), seem to be of medical interest in humans (malabsorption syndromes, infant malnutrition, cardiovascular diseases, nonallergenic properties; Haenlein, 2004). Moreover, FA are reported to play an important role in the techno-functional properties of cheese making, including organoleptic properties and cheese yield (Martin, 2008).

Therefore, interest in FA composition has been increasing over the last $10 \mathrm{yr}$. Many studies have investigated the short-term improvement of FA composition based on a feeding approach (Chilliard et al., 2001, 2002, 2003, 2008; Chilliard and Ferlay, 2004; Ollier et al., 2009). Another permanent and cumulative approach is to focus on genetic selection. To study the feasibility of a genetic change of milk FA composition, genetic parameters for FA have to be estimated. A few studies on the estimation of the genetic parameters in cattle were published several years ago (Renner and Kosmack, 1974; Karijord et al., 1982) and more recently (Soyeurt et al., 2007; Bobe et al., 2008; Soyeurt and Gengler, 2008; Stoop et al., 2008; Gion et al., 2011). To our knowledge, no equivalent study on FA composition in goats has been published to date. One genetic study on Norwegian goats (Skjevdal, 1979) reported a heritability of goat flavor of approximately 0.25 , providing an indirect and rough estimation of C8:0 heritability.

In France, since 2008, an important research and development project has been performed to establish detailed phenotypes for milk composition (FA and proteins) and genotypes in cattle, sheep, and goats. The "PhénoFinLait" project is supported by a consortium of scientific and economic stakeholders from the milk industry (Brochard et al., 2009). The project involved a large-scale, on-farm phenotyping scheme for milk components based on the use of mid-infrared (MIR) spectra. Estimation equations were developed by Ferrand et al. (2011) to estimate FA composition in a manner similar to previous work carried out on bovine species (Soyeurt et al., 2006a, 2011; Rutten et al., 2010). This method of estimation, already used by milk recording organizations for the estimation of fat or protein content, is faster and cheaper and allows the testing of many more samples and animals than the reference estimation method by GC; MIR spectra estimates, however, are less reliable than GC.
The aim of the present study was to estimate genetic parameters for caprine milk FA using the MIR spectra collected during the PhénoFinLait project and genetic correlations of FA with milk production-related traits in primiparous goats.

\section{MATERIALS AND METHODS}

\section{Animals and Milk Sampling}

From December 2009 to December 2010, 269,296 milk samples were collected from 71,384 goats from the 2 main French dairy breeds (Alpine and Saanen) in 210 herds, as part of the PhénoFinLait project. Samples were analyzed by using 6 MIR spectrometers (MilkoScan FT6000 and MilkoScan FT+; Foss Electric, Hillerød, Denmark) in 3 laboratories. Herds were selected using several criteria: they had to be part of French milk recording, located in areas with a high concentration of goat herds, and close to a laboratory producing MIR spectra. Moreover, they had to be representative of the most common goat husbandry systems in France; that is, a feeding regimen using forages, concentrates, or both, with a kidding period in autumn or spring. Additionally, herds were chosen according to their high AI rate, to further conduct QTL detection in a daughter design. For each herd involved in the program, the database contained 2 to 6 test dates (TD) with individual MIR spectral information of goats. Additional information on SCC, milk yield, and fat and protein contents, collected monthly by the milk recording organization, were extracted from the national goat database (CTIG, Centre de Traitement de l'Information Génétique, INRA, Jouy-en-Josas, France).

Only data from the first lactation were considered for estimation of genetic parameters. Preliminary studies showed that fat content showed a considerable residual standard error during the earlier stages of lactation (between 5 and 20 DIM). Therefore, records with DIM of $<20$ or $>364$ were discarded. Additional edits were applied according to the following inclusion criteria: (1) herds with at least $5 \mathrm{FA}$ profile records by herd within test-day (HTD) classes; (2) animals from Alpine and Saanen purebred, with known sires and at least 2 TD during the lactation; and (3) sires with at least 5 daughters.

Moreover, selection was applied based on the milk recording method. Only methods A and AT were considered: in the A milk recording method, 2 samples of milk (one from the evening and one from the morning) were collected but only one sample (a mix of both collected samples) was analyzed; in the AT milk recording 
Table 1. Statistical parameters describing the accuracy of the predicted FA contents in milk for validation set ( $\mathrm{n}=60$ goat); unpublished update of Ferrand et al. (2011)

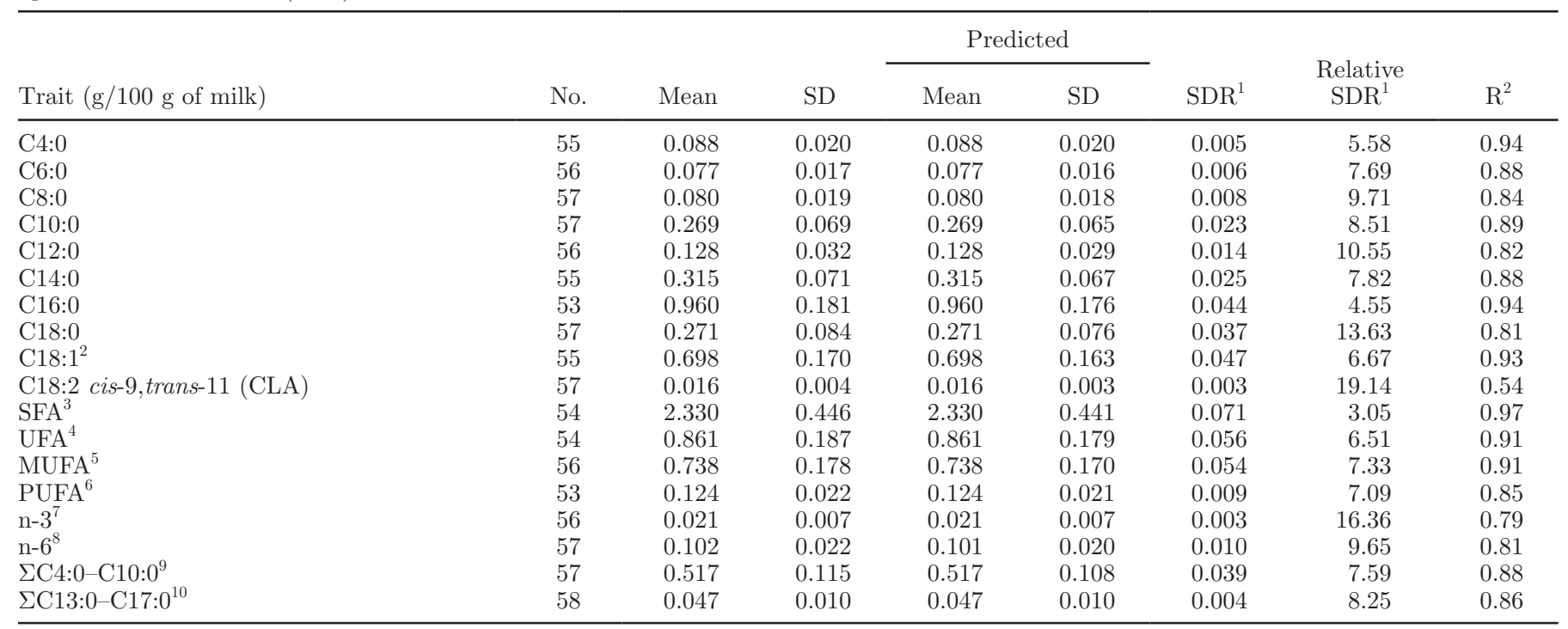

${ }^{1} \mathrm{SDR}=$ residual standard deviation; relative $\mathrm{SDR}=\mathrm{SDR} /$ reference mean $(\%)$.

${ }^{2} \mathrm{C} 18: 1$ is the sum of estimates of trans- 6 , trans- 8 , trans-9, trans-10, trans-11, trans-12, trans-13, trans-16, cis-9, cis-11, cis-12, cis-13, and cis-15 C18:1.

${ }^{3} \mathrm{SFA}$ include saturated C4, C5, C6, C7, C8, C9, C10, C11, C12, C13, C14, C14 iso, C15, C15 iso, C15 anteiso, C16, C16 iso, C17, C17 iso, C17 anteiso, $\mathrm{C} 18, \mathrm{C} 18$ iso, C20, C21, C22, C23, and C24.

${ }^{4} \mathrm{UFA}=$ sum of MUFA and PUFA.

${ }^{5}$ MUFA include C12:1 cis, C14:1 cis-9, C15:1 cis-10, C16:1 cis-9, C16:1 trans-7, C17:1 cis-10, the total of C18:1, C20:1 cis-9, and C20:1 cis-11. ${ }^{6}$ PUFA include C18:2 trans-9, cis-12, C18:2 cis-9, cis-12, C18:2 cis-9,trans-11, C20:2n-6, C18:3n-6, C18:3n-3, C20:3n-6, C20:3n-3, C20:4n-6, and C20:5n-3.

${ }^{7}$ The n-3 group was directly estimated by a calibration equation comprising C18:1 cis-15, C18:3n-3, C20:3n-3, C20:5n-3, and C22:6n-3.

${ }^{8}$ The n-6 group was directly estimated by a calibration equation comprising C18:1 trans-12, C18:1 cis-12, C18:2 trans-9, cis-12, C18:2,cis-9,cis-12, C18:3n-6, C20:2n-6, C20:3n-6, C20:4n-6, and C22:2n-6.

${ }^{9}$ Sum of C4:0, C6:0, C8:0, and C10:0.

${ }^{10}$ Sum of C13:0, C15:0, and C17:0.

method, alternative samples from evenings or mornings were collected and analyzed.

\section{SCS and Milk Production Traits}

To study the SCC trait, we normalized the SCC distribution by a logarithmic transformation. The SCS was defined as SCS $=\log _{2}(\mathrm{SCC} / 100,000)+3$, as reported previously (Rupp et al., 2011).

The milk production traits used were TD records of milk yield (MY; kg), fat content (FC; g/ $\mathrm{kg}$ of milk), and protein content $(\mathbf{P C} ; \mathrm{g} / \mathrm{kg}$ of milk). Only records for which FA records were available were selected.

\section{FA Content}

Fatty acids were estimated (in g/100 g of milk) from calibration equations applied to the TD spectral data (Ferrand et al., 2011). The FA estimation equations were based on 149 samples from dairy Alpine goats and 50 samples from Saanen goats. The statistical pa- rameters describing the accuracy of the predicted FA based on a validation set of 60 goats, including the same proportion of animals from the 2 breeds than the calibration data set, are presented in Table 1 (unpublished update of Ferrand et al., 2011).

In our study, $18 \mathrm{FA}$ of interest in human health or industry and with acceptable reliability of calibration equations were selected. Our selection included 10 individual FA: butyric (C4:0), caproic (C6:0), caprylic (C8:0), capric (C10:0), lauric (C12:0), myristic (C14:0), palmitic (C16:0), stearic (C18:0), oleic (C18:1), and trans rumenic acid (C18:2 cis-9,trans-11; C18:2c9t11); and 8 groups of FA: SFA, UFA, MUFA, PUFA, n- 3 , n- 6 , sum of C4:0 to C10:0 ( $\Sigma$ C4:0-C10:0), and sum of C13:0 to $\mathrm{C} 17: 0$ ( $\Sigma \mathrm{C} 13: 0-\mathrm{C} 17: 0)$. Concerning the reliability of those traits, we used the relative error (relative residual standard deviation; Table 1) instead of coefficient of determination $\left(\mathrm{R}^{2}\right)$, which depends on the variability of the data set. The threshold was set at $13 \%$. For biological interest, we also considered C12:0, C18:0, n-3, and C18:2c9t11, which showed higher residual standard er- 
rors of $14.4,14.2,19.1$, and $22.2 \%$, respectively (Table 1 ). The results for these FA must therefore be treated with caution, as their estimates were less reliable.

Fatty acid estimates were expressed in $\mathrm{g} / 100 \mathrm{~g}$ of milk using milk density of $1.027 \mathrm{~g} / \mathrm{cm}^{3}$. To avoid taking into consideration glycerol, which is automatically included in the estimation, a correction coefficient of 0.95 was applied to the data. To study FA profiles in fat content, $\mathrm{FA}$ were also converted into contents in milk fat $(\mathrm{g} / 100 \mathrm{~g}$ of fat), using the total fat content estimated from the calibration equations (with relative error equal to $0.60 \%$ and $R^{2}>0.99$ ) and compared with GC data. Ferrand-Calmels et al. (2014) provided accuracies for FA for FA expressed in $\mathrm{g} / 100 \mathrm{~mL}$ of milk and in $\mathrm{g} / 100 \mathrm{~g}$ of $\mathrm{FA}$. The latter accuracies were calculated on the same set of data as in Ferrand et al. (2011), to which 134 Alpine and Saanen samples were added. Conversion affected differently the performance of the equation depending on the individual $\mathrm{FA}$ and the species. When compared with those observed in $\mathrm{g} / 100$ $\mathrm{mL}$ of milk, relative errors of estimations when FA were expressed in $\mathrm{g} / 100 \mathrm{~g}$ of fat were very similar but some $\mathrm{R}^{2}$ values were lower, such as those for C14:0 or C18:1. Generally, conversion to g/100 g of fat was associated with a small loss of accuracy for some FA.

To eliminate outliers, data deviating by more than 3 SD (8 records for C18:0) were discarded. The final edited data set contained 24,267 records from 7,349 animals of the Alpine breed and 20,992 records from 6,328 animals of the Saanen breed.

\section{Model}

In a preliminary step, the MIXED procedure of SAS (SAS Institute, 2008) was used to study the statistical significance of the following variation factors: HTD, lactation stage, breed, parity, month of kidding, sampling moment within lactation stage, and season of control. Considering all significant factors as random, the VARCOMP procedure of SAS (SAS Institute, 2008) was used to estimate the REML variance component of the factors, to quantify the percentage of variance explained by each factor. The HTD factor was the most important of all studied effects, because it explained 20 to $40 \%$ of the variance for the analyzed traits [18 FA explained in both units (i.e., g/100 g of milk and g/100 $\mathrm{g}$ of milk fat) as well as 4 milk production traits]. This factor is associated with the circumstances of the herd on the day of testing within each herd, particularly with feeding and, to a lesser extent, with other management factors. This factor was followed by factors of much less importance (0.002 to $4 \%$ of the variance). The second factor was lactation stage, followed by breed, parity, month of kidding, sampling moment within lactation stage, and finally season of control. It is worth noting that the above-mentioned effects explained a low proportion of variance for FA with lower contents in the milk. Moreover, one laboratory owned more than one analyzer, and samples from one single herd might not have been analyzed using the same analyzer. Also, calibration across analyzers is currently not satisfactory. Therefore, we decided to add the analyzer effect in the model.

Accordingly, variance components were estimated using a repeatability animal model with the REML software WOMBAT (Meyer, 2007). Because of the high number of traits in this analysis, single-trait models were first used to compute heritabilities and variance estimates, which were then used as priors to estimate covariances among traits. Because of computational challenges, 28 runs for 6 traits each were performed with a multitrait model. Analyses were run separately for Alpine and Saanen breeds.

The same model was used for all the traits considered:

$$
\begin{aligned}
\mathbf{y}= & \mathrm{HTD}+\mathrm{LS}+\mathrm{MK}+\mathrm{SC}+\mathrm{MLS} \\
& + \text { Analyzer }+\mathbf{Z} a+\mathbf{W} p+e,
\end{aligned}
$$

where $\mathbf{y}$ is the vector of test-day observations (2 to 6 , and 3 on average) for MY, FC, PC, SCS, SFA, UFA, MUFA, PUFA, C4:0, C6:0, C8:0, C10:0, C12:0, C14:0, C16:0, C18:0, C18:1, CLA, n-3, n-6, इC4:0-C10:0, and $\Sigma$ C13:0-C17:0. The fixed effects were HTD (428 and 391 classes in Alpine and Saanen breeds, respectively); LS = lactation stage (11 classes of $28 \mathrm{~d}$ each except for the eleventh stage which was $84 \mathrm{~d}$ ); $\mathrm{MK}=$ month of kidding ( 5 classes: January, February, March, April to August, September to December); $\mathrm{SC}=$ season of control [summer (July, August, September), autumn (October, November, December), winter (January, February, March), and spring (April, May, June)]; MLS = sampling moment within the lactation stage (i.e., morning or evening for AT milk recording method, day for A method; 33 classes); and Analyzer = laboratory analyzer (6 classes). The random elements were $a$, the random additive genetic effect; $p$, the random permanent environment effect; and $e$, the random residual effect. For random elements, the following distributions were assumed:

$$
\mathbf{a} \sim N\left(0, \mathbf{A} \sigma_{a}^{2}\right), \mathbf{e} \sim N\left(0, \mathbf{I} \sigma_{e}^{2}\right), \mathbf{p} \sim N\left(0, \mathbf{I} \sigma_{p}^{2}\right),
$$

where $\sigma_{a}^{2}$ is the additive genetic variance, $\sigma_{e}^{2}$ is the residual variance, $\sigma_{p}^{2}$ is the variance of permanent envi- 
ronment, $\mathbf{I}$ is an identity matrix, and $\mathbf{A}$ is the additive genetic relationship matrix; $\mathbf{Z}$ and $\mathbf{W}$ were the corresponding incidence matrices assigning observations to effects.

Six generations of ancestors were traced back and retained for the analysis. The total number of animals in the relationship matrix was 32,565 and 27,951 in Alpine and Saanen breeds, respectively.

\section{RESULTS AND DISCUSSION}

\section{Descriptive Statistics}

Table 2 summarizes elementary statistics for the studied traits. The mean values of MY, FC, and PC for Alpine and Saanen were $3.15 \mathrm{~kg} / \mathrm{d}, 37.4 \mathrm{~g} / \mathrm{kg}$, and 31.9 $\mathrm{g} / \mathrm{kg}$, respectively (Table 2) and were higher than those usually reported in Alpine and Saanen breeds (Belichon et al., 1999; Rupp et al., 2011). This difference was mainly due to the definition of the traits, because the results in the literature are standard traits for a 250-d lactation (Clement et al., 2002), but could also result from the selection of herds with high AI rates in our data set.

Average SCS in primiparous goats were $5.3( \pm 2.0)$ and $5.6( \pm 1.7)$ in the Alpine and Saanen breeds, respectively (Table 2). These values are in the same range as those reported previously in primiparous goats of the same breeds (Rupp et al., 2011), and correspond to an average SCC of about 1,000,000 cells $/ \mathrm{mL}$. The SCC values reported in dairy goats are known to be higher than those reported in various dairy sheep or cattle breeds (Rupp et al., 2011).

As expected, the estimated FA (SFA and UFA) represented approximately $4 \%$ of the milk constituent, with $3.44 \mathrm{~g} / 100 \mathrm{~g}$ of milk in the Alpine breed and $3.24 \mathrm{~g} / 100 \mathrm{~g}$ of milk in the Saanen breed. Results were slightly underestimated because the FA for which the quantities present are much weaker (trace amounts of UFA) are probably missing because the estimation method, based on wavelengths of MIR spectra, does not capture them. The estimates of FA content in the present study were close to the average GC values in the goat population used to establish calibration equations (Ferrand et al., 2011); for example, $2.35 \pm 0.48$, and $2.27 \pm 0.37 \mathrm{~g} / 100 \mathrm{~g}$ of milk for SFA in Alpine and Saanen breeds, respectively. Although FC was slightly higher in the Alpine breed (3.86 g/100 g of milk) compared with the Saanen breed (3.62 g/100 g of milk), milk FA profiles were very similar in fat content in both breeds (Table 2).

Regarding the average content of the various FA in $\mathrm{g} / 100 \mathrm{~g}$ of milk, similar ranges of values were reported previously in 7 breeds of Wallon primiparous cows

Table 2. Summary statistics of analyzed milk component traits in the Alpine and Saanen goat populations ${ }^{1}$

\begin{tabular}{|c|c|c|c|c|c|c|c|c|c|c|c|c|}
\hline \multirow[b]{3}{*}{ Trait $^{2}$} & \multicolumn{6}{|c|}{ Milk (g/100 g of milk) } & \multicolumn{6}{|c|}{ Milk fat (g/100 g of fat) } \\
\hline & \multicolumn{3}{|c|}{ Alpine } & \multicolumn{3}{|c|}{ Saanen } & \multicolumn{3}{|c|}{ Alpine } & \multicolumn{3}{|c|}{ Saanen } \\
\hline & Mean & $\mathrm{SD}$ & $\mathrm{CV}(\%)$ & Mean & $\mathrm{SD}$ & $\mathrm{CV}(\%)$ & Mean & $\mathrm{SD}$ & $\mathrm{CV}(\%)$ & Mean & $\mathrm{SD}$ & $\mathrm{CV}(\%)$ \\
\hline Milk yield (kg/d) & 3.12 & 0.84 & 27 & 3.19 & 0.86 & 27 & & & & & & \\
\hline Fat (g/kg of milk) & 38.63 & 6.88 & 18 & 36.23 & 7.04 & 19 & & & & & & \\
\hline Protein (g/kg of milk) & 32.67 & 3.47 & 11 & 31.17 & 3.08 & 10 & & & & & & \\
\hline SCS & 5.27 & 2.01 & 38 & 5.58 & 1.66 & 30 & & & & & & \\
\hline $\mathrm{C} 4: 0$ & 0.09 & 0.02 & 20 & 0.09 & 0.02 & 22 & 2.51 & 0.30 & 12 & 2.59 & 0.31 & 12 \\
\hline C6:0 & 0.09 & 0.02 & 19 & 0.08 & 0.02 & 20 & 2.48 & 0.15 & 6 & 2.49 & 0.15 & 6 \\
\hline $\mathrm{C} 8: 0$ & 0.10 & 0.02 & 18 & 0.09 & 0.02 & 21 & 2.78 & 0.19 & 7 & 2.71 & 0.19 & 7 \\
\hline C10:0 & 0.34 & 0.07 & 19 & 0.32 & 0.07 & 21 & 9.80 & 1.28 & 13 & 9.62 & 1.23 & 13 \\
\hline C12:0 & 0.16 & 0.03 & 19 & 0.14 & 0.03 & 21 & 4.62 & 0.78 & 17 & 4.22 & 0.75 & 18 \\
\hline C14:0 & 0.39 & 0.07 & 18 & 0.37 & 0.07 & 20 & 11.06 & 1.45 & 13 & 11.26 & 1.41 & 12 \\
\hline C16:0 & 0.99 & 0.18 & 18 & 0.95 & 0.19 & 20 & 27.87 & 1.34 & 5 & 28.46 & 1.24 & 4 \\
\hline C18:0 & 0.28 & 0.07 & 25 & 0.27 & 0.07 & 26 & 8.02 & 0.92 & 11 & 8.28 & 0.97 & 12 \\
\hline $\mathrm{C} 18: 1$ & 0.72 & 0.15 & 21 & 0.68 & 0.15 & 22 & 20.36 & 1.90 & 9 & 20.22 & 1.80 & 9 \\
\hline C18:2 cis-9,trans-11 (CLA) & 0.02 & 0.01 & 20 & 0.02 & 0.01 & 22 & 0.51 & 0.099 & 19 & 0.49 & 0.10 & 20 \\
\hline SFA & 2.62 & 0.46 & 17 & 2.46 & 0.48 & 19 & 73.74 & 2.09 & 3 & 73.49 & 1.84 & 2 \\
\hline Unsaturated FA & 0.82 & 0.18 & 22 & 0.78 & 0.17 & 22 & 23.06 & 2.01 & 9 & 23.2 & 1.85 & 8 \\
\hline MUFA & 0.73 & 0.15 & 20 & 0.68 & 0.15 & 22 & 20.43 & 0.97 & 5 & 20.45 & 0.93 & 4 \\
\hline PUFA & 0.14 & 0.03 & 21 & 0.13 & 0.03 & 21 & 4.11 & 0.67 & 16 & 4.03 & 0.63 & 6 \\
\hline n-3 & 0.03 & 0.01 & 17 & 0.03 & 0.01 & 18 & 0.80 & 0.13 & 16 & 0.81 & 0.12 & 15 \\
\hline $\mathrm{n}-6$ & 0.11 & 0.02 & 19 & 0.1 & 0.02 & 20 & 3.21 & 0.40 & 12 & 3.2 & 0.41 & 13 \\
\hline$\Sigma \mathrm{C} 4: 0-\mathrm{C} 10: 0$ & 0.64 & 0.11 & 17 & 0.59 & 0.11 & 19 & 18.08 & 1.13 & 6 & 17.74 & 1.07 & 6 \\
\hline$\Sigma \mathrm{C} 13: 0-\mathrm{C} 17: 0$ & 0.06 & 0.01 & 14 & 0.06 & 0.01 & 15 & 1.76 & 0.14 & 8 & 1.78 & 0.14 & 8 \\
\hline
\end{tabular}

${ }^{1}$ Alpine: 7,349 goats and 24,267 test-day records; Saanen: 6,328 goats and 20,992 test-day records.

${ }^{2}$ See Table 1 for description of traits. 
(Soyeurt et al., 2007). For instance, average estimates (SD) in cattle for C12:0, C14:0, C16:0, C18:0, C18:1, C18:2c9t11, SFA, and MUFA were 0.13 (0.15), 0.44 (0.30), 1.24 (0.72), 0.51 (0.27), 0.95 (0.72), 0.07 (0.02), $2.86(2.62)$, and $1.02(0.73) \mathrm{g} / 100 \mathrm{~g}$ of milk, respectively.

Generally, mean contents of the various FA in $\mathrm{g} / 100 \mathrm{~g}$ of milk in our data set were similar to mean contents in the validation set, with an average deviation (absolute value) of $0.6 \mathrm{SD}$ between the validation and the current study populations (Tables 1 and 2). In some cases, however, differences were higher, such as those for CLA (1.00 SD) or n-3 (1.30 SD), for example. This difference could be due to the low accuracy of prediction for those FA, but we cannot exclude real biological differences between the validation and the study populations. Therefore, the accuracies shown in Table 1 might not apply to the current data set for those FA.

As far as FA profiles within fat content were concerned, goats showed similar SFA values to cattle and sheep, with approximately $73.5 \mathrm{~g} / 100 \mathrm{~g}(\mathrm{SD} \approx 2)$ of fat in goat milk versus $70 \mathrm{~g} / 100 \mathrm{~g}$ of fat in cow milk (Soyeurt et al., 2007) and 71.3 g/100 g of fat in sheep milk (Sanchez et al., 2010). As expected, it is mainly the contents of C6:0 to C12:0 SFA and especially C8:0 and $\mathrm{C} 10: 0$ that were higher in goats than in cattle. Indeed, the contents of $\mathrm{C} 6: 0, \mathrm{C} 8: 0, \mathrm{C} 10: 0$, and $\mathrm{C} 12: 0$ in were (SD) 2.48 (0.15), 2.78 (0.19), 9.80, (1.28), and $4.63(0.78) \mathrm{g} / 100 \mathrm{~g}$ of fat, respectively, in our Alpine goats, whereas corresponding values ( $\%$ of the total fat) were $2.23(0.17), 1.37(0.14), 3.03(0.43)$, and 4.11 (0.69) in Dutch Holstein-Friesian cattle (Stoop et al., 2008). Dairy sheep also had higher C10:0 contents (8.60 $\mathrm{g} / 100 \mathrm{~g}$ of fat) than dairy cattle (Sanchez et al., 2010).

\section{Heritability of Milk Yield, Fat and Protein Contents, and SCS}

Table 3 summarizes estimates of heritability and repeatability obtained with single-trait repeatability mixed models. Heritability of test-day MY, FC, PC, and SCS were 0.22, 0.23, 0.39, and 0.09 in Alpine and $0.24,0.20,0.40$, and 0.15 in Saanen breeds, respectively. Some authors (Schaeffer and Sullivan, 1994; Breznik et al., 2000) who estimated the variance components of test-day production traits (MY, FC, PC) of local Alpine and Saanen goats found heritability to be in the same range of values for milk $(0.20-0.30)$ but lower estimates for FC and PC (about $0.16-0.18$ and $0.20-0.24$, respectively) than those reported in the literature for lactation traits. In addition, the estimation of heritability during lactation using a comprehensive data set (8,700 Alpine and Saanen goats with 5 to 9 TD) computed by V. Clément (Institut de l'Élevage, Toulouse,
France; unpublished data) were in accordance with our study: from 0.12 to 0.28 for MY, from 0.18 to 0.35 for $\mathrm{FC}$, and from 0.28 to 0.48 for PC.

\section{Heritability of FA}

The heritabilities of SFA, UFA, MUFA, and PUFA were similar and close to the heritability of FC, with estimates ranging from 0.21 to 0.24 in both Alpine and Saanen breeds (Table 3 ). The same trend was found in cattle by Gion et al. (2011) and Soyeurt et al. (2007) and in other studies based on GC estimations of FA in cattle (Bobe et al., 2008; Stoop et al., 2008) as well as in sheep (Sanchez et al., 2010).

In the present study, most heritability estimates of individual FA, expressed in $\mathrm{g} / 100 \mathrm{~g}$ of milk, were in the range of 0.20 to 0.25 . The highest values were found for 3 medium-chain SFA, C10:0 to C14:0 $\left(\mathrm{h}^{2}\right.$ from 0.26 to 0.38 ), and lower values for the UFA C18:1 and C18:2c9t11 ( ${ }^{2}$ from 0.18 to 0.23 ). Similar trends were found in cattle for FA expressed on a milk basis $(\mathrm{g} / \mathrm{L})$ or on a fat basis (wt/wt\%) by Bobe et al. (2008) and Stoop et al. (2008), with higher heritabilities for C10:0 (i.e., 0.71; Stoop et al., 2008) and C12:0 (i.e., 0.43; Bobe et al., 2008). However, much lower heritabilities have been estimated for the Italian Holstein-Friesian population: $0.07,0.03$, and 0.08 , respectively, for C14:0, C16:0, and C18:0 (Mele et al., 2009). Moreover, different results were found in the Churra sheep breed (Sanchez et al., 2010) for UFA groups, in which estimates were not significantly different from zero. Saturated FA are the major constituent of milk fat, around $73 \%$ in our study (Table 2), and individual SFA (i.e., C6:0 to C16:0) are synthesized de novo in the mammary gland and elongated by 2 main enzymes: fatty acid synthase and acetyl CoA carboxylase (Chilliard et al., 2001). In contrast, UFA (C18:1, C18:2c9t11), which are provided by the diet and directly taken from the blood after modification by biohydrogenation in the rumen (Polan et al., 1964; Harfoot and Hazlewood, 1988) might be less genetically determined and therefore less heritable compared with SFA.

However, the accuracy of FA estimates from MIR spectra might also have affected the heritability estimates. Indeed, Rutten et al. (2010) reported that deviations from the average "true" genetic parameters were strongly related to the number of calibration samples and on whether the MIR-based FA prediction was weak or accurate for a given calibration sample size. The sample size has a direct effect but also indirectly affects the variability represented in the calibration data set. In brief, when the number of calibration samples is small $(\mathrm{n}=250)$, the heritability tended to be correctly estimated and accurate for FA for which the predicting 
Table 3. Heritability $\left(\mathrm{h}^{2}\right)$ and repeatability (rep) for milk component traits in the Alpine and Saanen goat populations from single-trait models ${ }^{1}$

\begin{tabular}{|c|c|c|c|c|c|c|c|c|c|c|c|c|}
\hline \multirow[b]{2}{*}{ Trait $^{2}$} & \multicolumn{6}{|c|}{ Milk (g/100 $\mathrm{g}$ of milk) } & \multicolumn{6}{|c|}{ Milk fat $(\mathrm{g} / 100 \mathrm{~g}$ of fat $)$} \\
\hline & $h^{2}$ & rep & $\mathrm{v}_{\mathrm{p}}{ }^{3}$ & $\mathrm{~h}^{2}$ & rep & $\mathrm{v}_{\mathrm{p}}$ & $\mathrm{h}^{2}$ & rep & $\mathrm{v}_{\mathrm{p}}$ & $h^{2}$ & rep & $\mathrm{v}_{\mathrm{p}}$ \\
\hline Milk yield & 0.22 & 0.66 & 48.87 & 0.24 & 0.64 & 51.89 & & & & & & \\
\hline Fat content & 0.23 & 0.45 & 26.09 & 0.20 & 0.46 & 26.61 & & & & & & \\
\hline Protein content & 0.39 & 0.71 & 8.09 & 0.40 & 0.70 & 6.39 & & & & & & \\
\hline $\mathrm{C} 6: 0$ & 0.24 & 0.48 & 0.17 & 0.21 & 0.49 & 0.18 & 0.37 & 0.56 & 1.18 & 0.36 & 0.53 & 1.26 \\
\hline C8:0 & 0.24 & 0.49 & 0.20 & 0.23 & 0.51 & 0.21 & 0.23 & 0.44 & 1.29 & 0.37 & 0.51 & 1.49 \\
\hline C10:0 & 0.30 & 0.53 & 2.71 & 0.26 & 0.54 & 2.69 & 0.28 & 0.48 & 55.10 & 0.26 & 0.43 & 51.44 \\
\hline C12:0 & 0.38 & 0.60 & 0.50 & 0.37 & 0.60 & 0.45 & 0.32 & 0.49 & 17.84 & 0.33 & 0.50 & 17.21 \\
\hline C14:0 & 0.32 & 0.51 & 2.16 & 0.26 & 0.50 & 2.05 & 0.25 & 0.47 & 46.15 & 0.23 & 0.49 & 51.45 \\
\hline C16:0 & 0.24 & 0.45 & 19.73 & 0.20 & 0.45 & 20.32 & 0.38 & 0.55 & 51.74 & 0.30 & 0.54 & 60.94 \\
\hline C18:0 & 0.23 & 0.43 & 2.32 & 0.21 & 0.45 & 2.50 & 0.47 & 0.61 & 36.86 & 0.44 & 0.60 & 43.68 \\
\hline PUFA & 0.22 & 0.39 & 0.37 & 0.23 & 0.40 & 0.35 & 0.30 & 0.47 & 16.44 & 0.24 & 0.48 & 17.52 \\
\hline $\mathrm{n}-3$ & 0.28 & 0.48 & 0.01 & 0.25 & 0.48 & 0.01 & 0.24 & 0.38 & 0.54 & 0.23 & 0.40 & 0.56 \\
\hline$n-6$ & 0.20 & 0.43 & 0.19 & 0.23 & 0.44 & 0.18 & 0.20 & 0.36 & 6.08 & 0.19 & 0.38 & 6.80 \\
\hline$\Sigma \mathrm{C} 4: 0-\mathrm{C} 10: 0$ & 0.24 & 0.49 & 7.41 & 0.23 & 0.51 & 7.86 & 0.22 & 0.41 & 36.67 & 0.38 & 0.48 & 39.07 \\
\hline$\Sigma \mathrm{C} 13: 0-\mathrm{C} 17: 0$ & 0.24 & 0.43 & 0.04 & 0.20 & 0.44 & 0.04 & 0.22 & 0.42 & 0.84 & 0.21 & 0.44 & 0.95 \\
\hline
\end{tabular}

${ }^{1}$ Alpine: 7,349 goats and 24,267 test-day records; Saanen: 6,328 goats and 20,992 test-day records.

${ }^{2}$ See Table 1 for description of traits.

${ }^{3} \mathrm{v}_{\mathrm{p}}=$ phenotypic variance estimated $\left(\mathrm{v}_{\mathrm{p}}=\mathrm{v}_{\mathrm{g}}+\mathrm{v}_{\mathrm{ep}}+\mathrm{v}_{\mathrm{r}}\right.$, where $\mathrm{v}_{\mathrm{g}}=$ genetic variance, $\mathrm{v}_{\mathrm{ep}}=$ permanent environmental variance, $\mathrm{v}_{\mathrm{r}}=$ residual) $\mathrm{SE}$ between 0.02 and 0.04, with mean and median SE at 0.03 .

ability of MIR spectra was good. Heritability, however, tended to be underestimated, on average, for FA for which the predicting ability of MIR spectra was weak with higher variation around the "true value"; for example, that estimated from GC data. Accordingly, heritability estimates of goat FA might be underestimated in our study, especially for FA such as C18:2c9t11 or for the n-3 FA group. Therefore, our data show little evidence that de novo synthesized FA have higher heritabilities than FA derived from the blood.

The heritability was higher for most FA when expressed in $\mathrm{g} / 100 \mathrm{~g}$ of fat than when expressed in $\mathrm{g} / 100 \mathrm{~g}$ of milk (Table 3 ). The opposite trend was found in bovine species by Gion et al. (2011) and Soyeurt et al. (2007). In our study, the highest heritabilities were found for several short- and long-chain FA (C4:0, $\mathrm{C} 16: 0$, and $\mathrm{C} 18: 0)$, with estimates ranging from 0.30 to 0.49 when expressed in $\mathrm{g} / 100 \mathrm{~g}$ of milk fat (Table 3), whereas the highest values were found for medium FA when expressed in $\mathrm{g} / 100 \mathrm{~g}$ of milk. Because high variation around the true value is expected for heritability of FA with weak predictions, the difference in heritability according to unit (g/100 $\mathrm{g}$ of fat vs. $\mathrm{g} / 100 \mathrm{~g}$ of milk) could be spurious, at least for some FA. Indeed, Ferrand-Calmels et al. (2014), showed that, depending on the unit, relative errors of estimation were similar but some $\mathrm{R}^{2}$ values were lower for FA expressed in $\mathrm{g} / 100 \mathrm{~g}$ of fat compared with FA expressed in $\mathrm{g} / 100 \mathrm{~g}$ of milk, especially for $\mathrm{C} 16: 0$ ( $\mathrm{R}^{2}$ of 0.96 and 0.69 , respectively) or $\mathrm{C} 18: 0$ ( $\mathrm{R}^{2}$ of 0.86 and 0.55 , respectively). However, in general, the 3 specific short- and medium-chain FA in goat milk (C6:0, C8:0, and C10:0) showed some of the highest heritability estimates (ranging from 0.21 to 0.37 , with an average of 0.30 ).

The repeatability for test-days of FA and FC traits were moderate, with an average of 0.46 and 0.47 for both units in Alpine and Saanen breeds, respectively. Our results were in agreement with Soyeurt et al. (2006b), whose estimates were between 0.41 and 0.61 . The lowest repeatability was found for CLA, in agreement with the poor performance of the estimation for this FA. Higher repeatabilities were found for production traits (MY, PC, and SCS), which ranged from 0.58 to 0.71 , than for FA. The same trend was described in sheep, with repeatabilities ranging from 0.06 to 0.14 for FA groups (SFA, MUFA, PUFA) and from 0.18 to 0.46 for production traits (MY, PC, and FC).

The same trend has been described in other ruminant species such as sheep, with repeatabilities ranging from 0.18 to 0.46 against $\sim 0.08$ for SFA (Sanchez et al., 2010 ), and cattle, with a repeatability of 0.58 against $\sim 0.41$ for FA (Soyeurt et al., 2007). 


\section{Genetic Correlations of Production Traits with FA Groups}

Table 4 shows genetic correlations between FA groups, expressed in $\mathrm{g} / 100 \mathrm{~g}$ of milk, and production traits for Saanen and Alpine breeds. In general, consistent correlations were found between the traits MY, FC, PC, and SCS compared with the average lactation traits in the same breeds described in the literature, as mentioned earlier for heritability estimates (Belichon et al., 1999; Rupp et al., 2011). A few minor discordances were observed, however. First, genetic oppositions between MY and FC and PC were slightly higher (genetic correlation between -0.35 and -0.42 ) than previous estimates in the same breeds; that is, -0.17 and -0.09 , respectively, in Alpine and Saanen (Belichon et al., 1999). Second, whereas the genetic correlation between FC and PC was in accordance with Belichon et al. (1999) for the Saanen breed (0.57 vs. 0.51), this correlation was lower in the Alpine breed (0.36 vs. 0.61). Therefore, the overall values obtained for the genetic parameters for milk production traits supported that both the present data set structure and the model used to compute FA genetic parameters seemed to be relevant.

Low correlations were found in both goat breeds between SCS and MY; this was in accordance with Rupp et al. (2011). Consistent with the results of the same authors, slightly higher and favorable genetic correlations were found between SCS and FC or PC, with the highest and only significant estimate $(-0.27)$ being between SCS and FC in the Alpine breed. Genetic correlations between SCS and the different FA groups were consistent with the correlation between SCS and FC (Table 4), except between SCS and PUFA in the Alpine breed $(-0.05$ and $0.28 \mathrm{in} \mathrm{g} / 100 \mathrm{~g}$ of milk or $\mathrm{g} / 100 \mathrm{~g}$ of fat, respectively). Accordingly, in the Alpine breed, a lower SCS seemed genetically unfavorably correlated with a lower content of PUFA in fat.

Correlations between MY and FA groups, in $\mathrm{g} / 100 \mathrm{~g}$ of milk, were generally moderate and negative, rang- ing from -0.25 to -0.34 , and in full agreement with the genetic correlation between MY and FC (Table $4)$. Results were mostly in agreement with bovine results reported by Gion et al. (2011) and Soyeurt et al. (2007). The only difference was observed between MY and UFA, for which the correlation was weaker in both goat breeds than in Gion et al. (2011), with -0.30 in goats versus -0.65 in cattle. Such negative correlations could be associated with the dilution of FA in milk, as the greater the quantity of milk, the lower the content (Soyeurt et al., 2007). As in cattle, moderate phenotypic correlations were found between MY and FA, ranging from 0.28 to -0.45 for both units and in both breeds. Moreover, phenotypic correlations obtained for both breeds and both units were generally lower than genetic correlations but present the same direction of variation.

Genetic correlations between MY or PC, on the one hand, and FA groups expressed in $\mathrm{g} / 100 \mathrm{~g}$ of fat, on the other hand, were weak and almost all nonsignificantly different from zero (Table 5), indicating that selection on $\mathrm{MY}$ and $\mathrm{PC}$ is not expected to modify the global FA profile within FC in goats. These results were different from those reported in cattle by Soyeurt et al.(2007) and Gion et al. (2011), who estimated negative correlations of -0.09 (Soyeurt et al., 2007) and -0.12 (Gion et al., 2011) with SFA and positive correlations of 0.33 with UFA (Gion et al., 2011) and 0.22 with MUFA (Soyeurt et al., 2007). In cattle, the results therefore imply that selection on milk yield could slightly affect the FA profile.

As expected, genetic correlations between $\mathrm{FC}$ and FA groups expressed in $\mathrm{g} / 100 \mathrm{~g}$ of milk were high, ranging from 0.63 to 0.94 (Table 4). High and consistent correlations between FC and MUFA were found in both breeds (0.86-0.88). In the Saanen breed, the correlation between FC and SFA was highest (0.94) and significantly higher than in the Alpine breed (0.63). The genetic correlations between FC and FA groups expressed in $\mathrm{g} / 100 \mathrm{~g}$ of fat led to further investigation of the asso-

Table 4. Genetic correlations between milk yield (MY), fat content (FC), protein content (PC), SCS, SFA, unsaturated FA (UFA), MUFA, and PUFA contents in milk (g/100 $\mathrm{g}$ of milk) of Alpine (above the diagonal) and Saanen (below the diagonal) goats ${ }^{1,2}$

\begin{tabular}{lccccrrrr}
\hline & MY & FC & PC & SCS & SFA & UFA & MUFA & PUFA \\
\hline MY & & -0.38 & -0.42 & $0.09^{\mathrm{NS}}$ & -0.31 & -0.34 & -0.33 & -0.26 \\
FC & -0.35 & & 0.36 & -0.27 & 0.63 & 0.79 & 0.88 & 0.67 \\
PC & -0.36 & 0.57 & & $0.06^{\mathrm{NS}}$ & 0.31 & 0.43 & 0.41 & 0.52 \\
SCS & $0.07^{\mathrm{NS}}$ & $-0.11^{\mathrm{NS}}$ & $-0.20^{\mathrm{NS}}$ & & -0.27 & $-0.21^{\mathrm{NS}}$ & $-0.26^{\mathrm{NS}}$ & $-0.05^{\mathrm{NS}}$ \\
SFA & -0.30 & 0.94 & 0.50 & $-0.09^{\mathrm{NS}}$ & & 0.81 & 0.93 & 0.62 \\
UFA & -0.30 & 0.70 & 0.47 & $-0.05^{\mathrm{NS}}$ & 0.89 & & 0.91 & 0.77 \\
MUFA & -0.31 & 0.86 & 0.50 & $-0.08^{\mathrm{NS}}$ & 0.95 & 0.95 & 0.64 \\
PUFA & -0.25 & 0.75 & 0.59 & $-0.05^{\mathrm{NS}}$ & 0.74 & 0.81 & 0.75 \\
\hline
\end{tabular}

${ }^{1} \mathrm{SE}$ between 0.02 and 0.13 .

${ }^{2}$ All values are significantly different from zero except those marked (NS) as not significantly different. 
Table 5. Genetic correlations between milk yield (MY), fat content (FC), protein content (PC), SCS, SFA, unsaturated FA (UFA), MUFA, and PUFA contents in milk fat (g/100 g of fat) of Alpine (above the diagonal) and Saanen (below the diagonal) goats ${ }^{1,2}$

\begin{tabular}{|c|c|c|c|c|c|c|c|c|}
\hline & MY & $\mathrm{FC}$ & $\mathrm{PC}$ & SCS & SFA & UFA & MUFA & PUFA \\
\hline MY & & -0.38 & -0.42 & $0.09^{\mathrm{NS}}$ & $0.10^{\mathrm{NS}}$ & $-0.04^{\mathrm{NS}}$ & $0.05^{\mathrm{NS}}$ & 0.13 \\
\hline $\mathrm{FC}$ & -0.35 & & 0.36 & -0.27 & 0.16 & $-0.05^{\mathrm{NS}}$ & 0.21 & -0.49 \\
\hline $\mathrm{PC}$ & -0.36 & 0.57 & & $0.06^{\mathrm{NS}}$ & $-0.04^{\mathrm{NS}}$ & $0.06^{\mathrm{NS}}$ & 0.16 & $0.08^{\mathrm{NS}}$ \\
\hline SCS & $0.07^{\mathrm{NS}}$ & $-0.11^{\mathrm{NS}}$ & $-0.20^{\mathrm{NS}}$ & & $-0.16^{\mathrm{NS}}$ & $0.08^{\mathrm{NS}}$ & $-0.11^{\mathrm{NS}}$ & 0.28 \\
\hline SFA & $0.04^{\mathrm{NS}}$ & 0.33 & 0.11 & $-0.08^{\mathrm{NS}}$ & & -0.51 & -0.34 & -0.39 \\
\hline UFA & $-0.01^{\mathrm{NS}}$ & $-0.04^{\mathrm{NS}}$ & $0.00^{\mathrm{NS}}$ & $0.11^{\mathrm{NS}}$ & -0.51 & & 0.54 & 0.43 \\
\hline MUFA & $-0.01^{\mathrm{NS}}$ & 0.17 & $0.10^{\mathrm{NS}}$ & $0.00^{\mathrm{NS}}$ & -0.24 & 0.69 & & 0.16 \\
\hline PUFA & $0.10^{\mathrm{NS}}$ & -0.29 & $0.14^{\mathrm{NS}}$ & $0.04^{\mathrm{NS}}$ & -0.53 & 0.53 & 0.30 & \\
\hline
\end{tabular}

${ }^{1}$ SE between 0.02 and 0.13 .

${ }^{2}$ All values are significantly different from zero except those marked (NS) as not significantly different.

ciation between $\mathrm{FC}$ and relative fractions of the various FA groups within FC (Table 5). When expressed in $\mathrm{g} / 100 \mathrm{~g}$ fat, SFA were negatively correlated with UFA $(-0.24$ to -0.53$)$ due to the definition of the traits. These results were consistent with cattle studies, in which genetic correlations ranging from -0.12 to -0.75 were found between SFA and UFA in Montbéliarde, Normande, and Holstein breeds (Gion et al., 2011), and a genetic correlation of -0.44 between SFA and MUFA in 7 cattle breeds (Soyeurt et al., 2007). Genetic correlations between FC and SFA were positive (0.16 and $0.33)$ although lower than in cattle $[0.68$ and 0.76 in Gion et al. (2011) and Soyeurt et al. (2007)], and were close to zero between FC and UFA ( -0.04 to -0.05$)$. The lack of association with UFA resulted from opposite genetic correlations with the 2 subgroups of UFA (i.e., MUFA and PUFA), which were positively (0.16 to $0.17)$ and negatively $(-0.29$ to -0.49$)$ associated with FC, respectively (Table 5). The main difference with cattle was the negative genetic correlations with MUFA and therefore UFA $(-0.22$ in Soyeurt et al., 2007; -0.64 in Gion et al., 2011). As a consequence, selection on FC in goats would be expected to slightly increase the content of SFA and MUFA but lower that of PUFA.

Differences between goat genetic parameters estimated here and cattle data might be due to true biological differences but also, at least to some extent, to a lack of accuracy in our data set. Indeed, as for heritability estimates, Rutten et al. (2010) showed that the number of calibration samples and the predicting ability of MIR spectra greatly affect the genetic correlation estimates between predicted FA and the "true" value (GC measures), and even greater genetic correlation between predicted FA and other traits or among FA. In brief, when calibration accuracy was low (e.g., unsaturated C16:0 in Rutten et al., 2010), the genetic correlation between the true and estimated FA showed a broad range of values ranging from 0.25 to 0.69 when the calibration data set was reduced $(\mathrm{n}=250)$ and only reached 0.86 for a calibration data set of 1,815 samples. Rutten et al. (2010) concluded that a calibration data set of 1,000 samples was needed to obtain reasonably accurate genetic correlation estimates. Genetic correlations with predicted FA in our study might therefore be questionable, especially where accuracies of prediction were weak.

\section{Phenotypic and Genetic Correlations Between FA}

Table 6 shows genetic and phenotypic correlations between production traits and FA (g/100 g of milk) in the Alpine breed (results for the Saanen breed are in Supplemental Table S1; http://dx.doi.org/10.3168/ jds.2013-7328). Table 7 shows results with FA (expressed in $\mathrm{g} / 100 \mathrm{~g}$ of fat) for the Saanen breed (results for the Alpine breed are in Supplemental Table S2; http://dx.doi.org/10.3168/jds.2013-7328). These results should be considered with caution because of the accuracy issues mentioned above, but they give a first outline on trends in goats.

Regarding the unit of expression, most genetic correlations between all FA (SFA and UFA) were highly positive when expressed in $\mathrm{g} / 100 \mathrm{~g}$ of milk (from 0.2 to 0.9 and 0.31 to 0.96, respectively, in Alpine and Saanen breeds) but presented high variations in $\mathrm{g} / 100 \mathrm{~g}$ of milk fat (from -0.78 to 0.68 and -0.59 to 0.78 , respectively, in Alpine and Saanen breeds). As expected regarding the nature of the traits, almost all genetic correlations between, first, the SFA group and individual SFA, and, second, between the UFA group and individual UFA were positive for both units. Similar results were obtained for Dutch (Stoop et al., 2008) and Belgian cattle (Soyeurt et al., 2007) as well as for Spanish Churra sheep (Sanchez et al., 2010). Genetic correlations between individual UFA and the SFA group, and between individual SFA and the UFA group in $\mathrm{g} / 100 \mathrm{~g}$ of milk fat were null or negative, except C4:0 with UFA (0.27) in Saanen (Table 7). Within the SFA group, C6:0 to 
Table 6. Genetic (below the diagonal) and phenotypic (above the diagonal) correlations between milk yield (MY), fat content (FC), protein content (PC), SFA, unsaturated FA (UFA), MUFA, PUFA, n-3, n-6, and individual FA contents expressed in $\mathrm{g} / 100 \mathrm{~g}$ of milk in Alpine goats ${ }^{1,2}$

\begin{tabular}{|c|c|c|c|c|c|c|c|c|c|c|c|c|c|c|c|c|c|c|c|c|c|}
\hline & MY & $\mathrm{FC}$ & $\mathrm{PC}$ & SFA & UFA & MUFA & PUFA & C4:0 & C6:0 & C8:0 & C10:0 & C12:0 & C14:0 & C16:0 & C18:0 & C18:1 & CLA & $\mathrm{n}-3$ & $\mathrm{n}-6$ & ¿C4-C10 & ¿C13-C17 \\
\hline MY & & -0.14 & -0.33 & $-0.10^{\mathrm{NS}}$ & $-0.14^{\mathrm{NS}}$ & -0.09 & -0.14 & $-0.08^{\mathrm{NS}}$ & $-0.08^{\mathrm{NS}}$ & $-0.06^{\mathrm{NS}}$ & $-0.08^{\mathrm{NS}}$ & $-0.11^{\mathrm{NS}}$ & $-0.08^{\mathrm{NS}}$ & -0.10 & -0.09 & -0.15 & -0.19 & -0.10 & -0.17 & -0.10 & -0.16 \\
\hline $\mathrm{FC}$ & -0.38 & & 0.21 & 0.36 & 0.43 & 0.59 & 0.42 & $0.22^{\mathrm{NS}}$ & 0.48 & 0.39 & 0.52 & 0.52 & 0.54 & 0.40 & 0.48 & 0.26 & 0.36 & 0.39 & 0.51 & 0.46 & 0.27 \\
\hline $\mathrm{PC}$ & -0.42 & 0.36 & & $0.10^{\mathrm{NS}}$ & 0.23 & 0.24 & 0.28 & $0.18^{\mathrm{NS}}$ & 0.23 & 0.36 & 0.26 & 0.29 & $0.22^{\mathrm{NS}}$ & 0.18 & 0.21 & 0.27 & 0.27 & 0.39 & 0.34 & 0.26 & 0.20 \\
\hline SFA & -0.31 & 0.63 & 0.31 & & 0.43 & 0.49 & 0.37 & $0.08^{\mathrm{NS}}$ & 0.39 & 0.35 & 0.46 & 0.48 & $0.26^{\mathrm{NS}}$ & 0.40 & 0.41 & 0.38 & 0.27 & 0.27 & 0.42 & 0.41 & 0.39 \\
\hline UFA & -0.34 & 0.79 & 0.43 & 0.81 & & 0.52 & 0.41 & 0.17 & 0.46 & 0.46 & 0.41 & 0.4 & $0.24^{\mathrm{NS}}$ & 0.38 & 0.39 & 0.38 & 0.36 & 0.40 & 0.38 & 0.42 & 0.32 \\
\hline MUFA & -0.33 & 0.88 & 0.41 & 0.93 & 0.91 & & 0.38 & 0.13 & 0.53 & 0.44 & 0.50 & 0.42 & 0.43 & 0.64 & 0.43 & 0.43 & 0.36 & 0.45 & 0.38 & 0.52 & 0.38 \\
\hline PUFA & -0.26 & 0.67 & 0.52 & 0.62 & 0.77 & 0.64 & & 0.27 & 0.38 & 0.26 & 0.31 & 0.40 & 0.39 & 0.36 & 0.36 & 0.27 & 0.37 & 0.37 & 0.46 & 0.39 & 0.20 \\
\hline C4:0 & $-0.21^{\mathrm{NS}}$ & $0.17^{\mathrm{NS}}$ & $0.23^{\mathrm{NS}}$ & 0.13 & 0.29 & 0.06 & 0.32 & & 0.46 & 0.46 & 0.24 & 0.25 & 0.29 & 0.41 & 0.42 & $0.24^{\mathrm{NS}}$ & 0.29 & 0.37 & 0.38 & 0.44 & 0.36 \\
\hline C6:0 & -0.31 & 0.82 & 0.37 & 0.64 & 0.84 & 0.84 & 0.52 & 0.66 & & 0.55 & 0.43 & 0.46 & 0.43 & 0.55 & 0.51 & 0.46 & 0.37 & 0.51 & 0.35 & 0.53 & 0.46 \\
\hline C8:0 & -0.37 & 0.50 & 0.51 & 0.56 & 0.87 & 0.67 & 0.29 & 0.63 & 0.89 & & 0.40 & 0.50 & 0.50 & 0.55 & 0.51 & 0.27 & 0.39 & 0.50 & 0.28 & 0.58 & 0.51 \\
\hline C10:0 & -0.31 & 0.87 & 0.35 & 0.85 & 0.72 & 0.79 & 0.47 & 0.37 & 0.69 & 0.68 & & 0.50 & 0.30 & 0.49 & 0.28 & 0.25 & 0.35 & 0.44 & 0.43 & 0.40 & 0.43 \\
\hline $\mathrm{C} 12: 0$ & -0.27 & 0.81 & 0.43 & 0.80 & 0.66 & 0.70 & 0.65 & 0.2 & 0.67 & 0.80 & 0.86 & & 0.47 & 0.49 & 0.37 & 0.35 & 0.38 & 0.47 & 0.44 & 0.53 & 0.50 \\
\hline C14:0 & -0.17 & 0.92 & 0.28 & 0.44 & 0.51 & 0.71 & 0.61 & 0.2 & 0.41 & 0.84 & 0.48 & 0.84 & & 0.51 & 0.23 & 0.42 & 0.35 & 0.43 & 0.42 & 0.40 & 0.44 \\
\hline C16:0 & -0.23 & $0.24^{\mathrm{NS}}$ & 0.29 & 0.59 & 0.76 & 0.83 & 0.59 & 0.5 & 0.75 & 0.89 & 0.85 & 0.74 & 0.69 & & 0.39 & 0.49 & 0.36 & 0.48 & 0.45 & 0.53 & 0.41 \\
\hline C18:0 & -0.24 & 0.75 & 0.38 & 0.70 & 0.73 & 0.70 & 0.55 & 0.62 & 0.84 & 0.85 & $0.26^{\mathrm{NS}}$ & 0.42 & 0.18 & 0.53 & & 0.32 & 0.29 & 0.44 & 0.40 & 0.44 & 0.28 \\
\hline C18:1 & -0.38 & $0.20^{\mathrm{NS}}$ & 0.43 & 0.71 & 0.65 & 0.79 & 0.30 & 0.31 & 0.74 & 0.31 & $0.31^{\mathrm{NS}}$ & 0.54 & 0.70 & 0.84 & 0.45 & & 0.38 & 0.37 & 0.48 & 0.48 & 0.44 \\
\hline $\mathrm{CLA}^{3}$ & -0.43 & 0.69 & 0.50 & 0.48 & 0.74 & 0.61 & 0.60 & 0.36 & 0.56 & 0.69 & 0.62 & 0.72 & 0.65 & 0.53 & 0.31 & 0.70 & & 0.26 & 0.41 & 0.42 & 0.37 \\
\hline $\mathrm{n}-3$ & -0.31 & 0.67 & 0.67 & 0.43 & 0.72 & 0.70 & 0.73 & 0.73 & 0.81 & 0.77 & 0.70 & 0.70 & 0.65 & 0.74 & 0.74 & 0.54 & 0.33 & & 0.42 & 0.50 & 0.46 \\
\hline $\mathrm{n}-6$ & -0.45 & 0.85 & 0.58 & 0.80 & 0.78 & 0.66 & 0.84 & 0.52 & 0.73 & 0.43 & 0.77 & 0.79 & 0.73 & 0.73 & 0.59 & 0.86 & 0.67 & 0.60 & & 0.52 & 0.50 \\
\hline$\Sigma \mathrm{C} 4: 0-\mathrm{C} 10: 0$ & -0.31 & 0.58 & 0.40 & 0.64 & 0.77 & 0.72 & 0.55 & 0.57 & 0.9 & 0.98 & 0.58 & 0.79 & 0.53 & 0.89 & 0.58 & 0.76 & 0.76 & 0.77 & 0.87 & & 0.51 \\
\hline$\Sigma \mathrm{C} 13: 0-\mathrm{C} 17: 0$ & -0.48 & 0.51 & 0.54 & 0.76 & 0.59 & 0.61 & $0.22^{\mathrm{NS}}$ & 0.53 & 0.76 & 0.89 & 0.76 & 0.79 & 0.78 & 0.68 & 0.31 & 0.77 & 0.72 & 0.75 & 0.89 & 0.85 & \\
\hline
\end{tabular}

${ }^{2}$ All values are significantly different from zero except those marked (NS) as not significantly different.

을 $\mathrm{C} 18: 2$ cis-9, trans- 11 
Table 7. Genetic (below the diagonal) and phenotypic (above the diagonal) correlations between milk yield (MY), fat content (FC), protein content (PC), SFA, unsaturated FA (UFA), MUFA, PUFA, n-3, n-6, and individual FA contents expressed in $\mathrm{g} / 100 \mathrm{~g}$ of fat in Saanen goats ${ }^{\mathrm{i}, 2}$

\begin{tabular}{|c|c|c|c|c|c|c|c|c|c|c|c|c|c|c|c|c|c|c|c|c|c|}
\hline & MY & $\mathrm{FC}$ & $\mathrm{PC}$ & SFA & UFA & MUFA & PUFA & C4:0 & C6:0 & C8:0 & C10:0 & C12:0 & C14:0 & C16:0 & C18:0 & C18:1 & CLA & $\mathrm{n}-3$ & $\mathrm{n}-6$ & $\Sigma \mathrm{C} 4-\mathrm{C} 10$ & $\Sigma \mathrm{C} 13-\mathrm{C} 17$ \\
\hline MY & & $-0.11^{\mathrm{NS}}$ & -0.30 & $0.02^{\mathrm{NS}}$ & $-0.08^{\mathrm{NS}}$ & $0.00^{\mathrm{NS}}$ & $0.00^{\mathrm{NS}}$ & $0.12^{\mathrm{NS}}$ & $0.16^{\mathrm{NS}}$ & $0.07^{\mathrm{NS}}$ & $0.02^{\mathrm{NS}}$ & $-0.07^{\mathrm{NS}}$ & $0.00^{\mathrm{NS}}$ & $0.00^{\mathrm{NS}}$ & $0.10^{\mathrm{NS}}$ & $0.01^{\mathrm{NS}}$ & $-0.07^{\mathrm{NS}}$ & $0.07^{\mathrm{NS}}$ & $-0.04^{\mathrm{NS}}$ & $0.09^{\mathrm{NS}}$ & $0.02^{\mathrm{NS}}$ \\
\hline $\mathrm{FC}$ & -0.35 & & 0.28 & $0.08^{\mathrm{NS}}$ & $0.00^{\mathrm{NS}}$ & 0.21 & -0.28 & $-0.17^{\mathrm{NS}}$ & $0.14^{\mathrm{NS}}$ & 0.21 & $0.07^{\mathrm{NS}}$ & $-0.09^{\mathrm{NS}}$ & -0.34 & $0.00^{\mathrm{NS}}$ & $0.14^{\mathrm{NS}}$ & $0.00^{\mathrm{NS}}$ & -0.21 & $-0.10^{\mathrm{NS}}$ & -0.32 & $0.09^{\mathrm{NS}}$ & -0.47 \\
\hline $\mathrm{PC}$ & -0.36 & 0.57 & & $0.05^{\mathrm{NS}}$ & $0.04^{\mathrm{NS}}$ & $0.04^{\mathrm{NS}}$ & $0.04^{\mathrm{NS}}$ & $-0.15^{\mathrm{NS}}$ & $-0.03^{\mathrm{NS}}$ & $0.14^{\mathrm{NS}}$ & $0.07^{\mathrm{NS}}$ & 0.23 & $-0.09^{\mathrm{NS}}$ & $-0.16^{\mathrm{NS}}$ & $-0.01^{\mathrm{NS}}$ & $-0.04^{\mathrm{NS}}$ & $-0.04^{\mathrm{NS}}$ & $0.01^{\mathrm{NS}}$ & $0.11^{\mathrm{NS}}$ & $0.13^{\mathrm{NS}}$ & -0.18 \\
\hline SFA & $0.04^{\mathrm{NS}}$ & 0.33 & $0.11^{\mathrm{NS}}$ & & -0.28 & -0.19 & -0.26 & $0.05^{\mathrm{NS}}$ & 0.26 & 0.30 & 0.22 & $0.09^{\mathrm{NS}}$ & $0.10^{\mathrm{NS}}$ & 0.22 & $0.07^{\mathrm{NS}}$ & -0.21 & $-0.10^{\mathrm{NS}}$ & $0.01^{\mathrm{NS}}$ & -0.22 & 0.28 & -0.23 \\
\hline UFA & $-0.01^{\mathrm{NS}}$ & $-0.04^{\mathrm{NS}}$ & $0.00^{\mathrm{NS}}$ & -0.51 & & 0.38 & 0.23 & $0.17^{\mathrm{VS}}$ & -0.27 & -0.26 & -0.22 & $-0.09^{\mathrm{NS}}$ & $-0.10^{\mathrm{NS}}$ & $-0.11^{\mathrm{NS}}$ & $0.00^{\mathrm{NS}}$ & 0.22 & $0.15^{\mathrm{NS}}$ & $-0.03^{\mathrm{NS}}$ & $0.17^{\mathrm{NS}}$ & -0.26 & $0.07^{\mathrm{NS}}$ \\
\hline MUFA & $-0.01^{\mathrm{NS}}$ & $0.17^{\mathrm{NS}}$ & $0.10^{\mathrm{NS}}$ & -0.24 & 0.69 & & $0.07^{\mathrm{NS}}$ & $0.08^{\mathrm{NS}}$ & $0.11^{\mathrm{NS}}$ & $0.03^{\mathrm{NS}}$ & -0.25 & -0.22 & -0.36 & $-0.13^{\mathrm{NS}}$ & 0.30 & 0.37 & $-0.14^{\mathrm{NS}}$ & $-0.10^{\mathrm{NS}}$ & $-0.06^{\mathrm{NS}}$ & $-0.03^{\mathrm{NS}}$ & -0.18 \\
\hline PUFA & $0.10^{\mathrm{NS}}$ & -0.29 & 0.14 & -0.53 & 0.53 & 0.30 & & $-0.04^{\mathrm{NS}}$ & $-0.12^{\mathrm{NS}}$ & $-0.16^{\mathrm{NS}}$ & $-0.09^{\mathrm{NS}}$ & 0.19 & $0.14^{\mathrm{NS}}$ & -0.29 & $-0.03^{\mathrm{NS}}$ & $0.11^{\mathrm{NS}}$ & $0.17^{\mathrm{NS}}$ & 0.30 & 0.39 & $-0.10^{\mathrm{NS}}$ & 0.27 \\
\hline C4:0 & $0.13^{\mathrm{NS}}$ & -0.33 & -0.19 & $0.05^{\mathrm{NS}}$ & 0.27 & -0.20 & -0.17 & & 0.23 & $0.16^{\mathrm{NS}}$ & -0.22 & -0.38 & -0.32 & $-0.13^{\mathrm{NS}}$ & 0.37 & 0.30 & $-0.03^{\mathrm{NS}}$ & 0.30 & $0.03^{\mathrm{NS}}$ & 0.22 & $-0.06^{\mathrm{NS}}$ \\
\hline C6:0 & 0.27 & $0.17^{\mathrm{NS}}$ & 0.10 & 0.59 & -0.41 & $0.16^{\mathrm{NS}}$ & $-0.15^{\mathrm{NS}}$ & 0.47 & & 0.51 & 0.29 & $0.02^{\mathrm{NS}}$ & -0.19 & $-0.13^{\mathrm{NS}}$ & 0.39 & $-0.18^{\mathrm{NS}}$ & -0.24 & $0.06^{\mathrm{NS}}$ & $-0.17^{\mathrm{NS}}$ & 0.22 & -0.32 \\
\hline C8:0 & 0.14 & 0.34 & 0.36 & 0.50 & -0.39 & $0.05^{\mathrm{NS}}$ & -0.21 & 0.36 & 0.78 & & 0.35 & $0.15^{\mathrm{NS}}$ & -0.18 & -0.23 & 0.20 & $-0.15^{\mathrm{NS}}$ & $-0.05^{\mathrm{NS}}$ & $-0.03^{\mathrm{NS}}$ & $-0.09^{\mathrm{NS}}$ & 0.50 & -0.38 \\
\hline C10:0 & $0.01^{\mathrm{NS}}$ & 0.28 & 0.36 & 0.36 & -0.36 & -0.34 & $-0.10^{\mathrm{NS}}$ & -0.29 & 0.40 & 0.59 & & 0.41 & 0.25 & $-0.09^{\mathrm{NS}}$ & $-0.13^{\mathrm{NS}}$ & -0.38 & $0.07^{\mathrm{NS}}$ & $0.03^{\mathrm{NS}}$ & $-0.01^{\mathrm{NS}}$ & 0.36 & $-0.15^{\mathrm{NS}}$ \\
\hline C12:0 & $-0.07^{\mathrm{NS}}$ & $0.18^{\mathrm{NS}}$ & 0.49 & $0.00^{\mathrm{NS}}$ & $-0.05^{\mathrm{NS}}$ & -0.25 & 0.29 & -0.59 & $0.03^{\mathrm{NS}}$ & 0.34 & 0.80 & & 0.39 & $-0.17^{\mathrm{NS}}$ & -0.31 & -0.34 & 0.20 & $0.16^{\mathrm{NS}}$ & 0.21 & 0.22 & $0.08^{\mathrm{NS}}$ \\
\hline C14:0 & $0.08^{\mathrm{NS}}$ & -0.35 & $-0.18^{\mathrm{NS}}$ & $-0.12^{\mathrm{NS}}$ & $0.01^{\mathrm{NS}}$ & -0.49 & 0.17 & -0.55 & -0.36 & -0.30 & 0.33 & 0.51 & & 0.21 & -0.27 & -0.27 & $0.14^{\mathrm{NS}}$ & 0.26 & $0.14^{\mathrm{NS}}$ & $-0.08^{\mathrm{NS}}$ & 0.32 \\
\hline C16:0 & $0.01^{\mathrm{NS}}$ & $-0.01^{\mathrm{NS}}$ & -0.37 & 0.14 & $-0.01^{\mathrm{NS}}$ & $-0.18^{\mathrm{NS}}$ & -0.38 & $-0.17^{\mathrm{NS}}$ & -0.26 & -0.51 & -0.38 & -0.44 & 0.33 & & $0.05^{\mathrm{NS}}$ & $-0.13^{\mathrm{NS}}$ & $-0.15^{\mathrm{NS}}$ & $-0.05^{\mathrm{NS}}$ & -0.29 & -0.23 & $0.02^{\mathrm{NS}}$ \\
\hline C18:0 & 0.28 & 0.07 & $-0.02^{\mathrm{NS}}$ & 0.30 & $-0.01^{\mathrm{NS}}$ & 0.42 & $-0.03^{\mathrm{NS}}$ & 0.56 & 0.64 & 0.30 & -0.27 & -0.44 & -0.31 & 0.21 & & $0.14^{\mathrm{NS}}$ & -0.35 & $0.07^{\mathrm{NS}}$ & -0.22 & 0.18 & -0.28 \\
\hline C18:1 & $0.18^{\mathrm{NS}}$ & $-0.17^{\mathrm{NS}}$ & -0.28 & -0.27 & 0.24 & 0.74 & $0.14^{\mathrm{NS}}$ & 0.48 & $-0.16^{\mathrm{NS}}$ & $-0.16^{\mathrm{NS}}$ & -0.69 & -0.62 & -0.51 & $-0.07^{\mathrm{NS}}$ & 0.22 & & $0.08^{\mathrm{NS}}$ & $-0.07^{\mathrm{NS}}$ & $0.07^{\mathrm{NS}}$ & $-0.14^{\mathrm{NS}}$ & $0.07^{\mathrm{NS}}$ \\
\hline $\mathrm{CLA}^{3}$ & $-0.18^{\mathrm{NS}}$ & $-0.20^{\mathrm{NS}}$ & $-0.05^{\mathrm{NS}}$ & -0.42 & 0.22 & $-0.14^{\mathrm{NS}}$ & 0.16 & $-0.12^{\mathrm{NS}}$ & -0.44 & $0.02^{\mathrm{NS}}$ & 0.30 & 0.35 & $0.11^{\mathrm{NS}}$ & -0.47 & -0.69 & $0.13^{\mathrm{NS}}$ & & $0.06^{\mathrm{NS}}$ & 0.33 & $0.00^{\mathrm{NS}}$ & 0.19 \\
\hline $\mathrm{n}-3$ & $0.20^{\mathrm{NS}}$ & -0.70 & $0.11^{\mathrm{NS}}$ & $-0.01^{\mathrm{NS}}$ & $-0.07^{\mathrm{NS}}$ & $0.00^{\mathrm{NS}}$ & 0.47 & 0.47 & 0.33 & $0.15^{\mathrm{NS}}$ & $0.06^{\mathrm{NS}}$ & $0.13^{\mathrm{NS}}$ & 0.26 & -0.17 & 0.39 & $-0.15^{\mathrm{NS}}$ & $-0.09^{\mathrm{NS}}$ & & 0.26 & $0.08^{\mathrm{NS}}$ & 0.28 \\
\hline $\mathrm{n}-6$ & $-0.11^{\mathrm{NS}}$ & -0.43 & 0.28 & -0.48 & 0.34 & $0.00^{\mathrm{NS}}$ & 0.65 & $0.00^{\mathrm{NS}}$ & -0.33 & $-0.10^{\mathrm{NS}}$ & $0.14^{\mathrm{NS}}$ & 0.35 & $0.12^{\mathrm{NS}}$ & -0.59 & -0.42 & $0.12^{\mathrm{NS}}$ & 0.66 & 0.37 & & $-0.03^{\mathrm{NS}}$ & 0.29 \\
\hline$\Sigma \mathrm{C} 4: 0-\mathrm{C} 10: 0$ & $0.18^{\mathrm{NS}}$ & 0.21 & 0.32 & 0.49 & -0.40 & $0.01^{\mathrm{NS}}$ & $-0.16^{\mathrm{NS}}$ & 0.42 & 0.33 & 0.94 & 0.64 & 0.34 & -0.22 & -0.52 & 0.31 & $-0.17^{\mathrm{NS}}$ & $0.07^{\mathrm{NS}}$ & 0.28 & $-0.02^{\mathrm{NS}}$ & & -0.28 \\
\hline ¿C13:0-C17:0 & $0.11^{\mathrm{NS}}$ & -0.71 & -0.38 & -0.63 & 0.20 & -0.27 & 0.30 & -0.23 & -0.58 & -0.64 & -0.32 & $-0.03^{\mathrm{NS}}$ & 0.48 & $0.12^{\mathrm{NS}}$ & -0.50 & 0.04 & 0.38 & 0.20 & 0.41 & -0.57 & \\
\hline
\end{tabular}

\section{${ }^{1} \mathrm{SE}$ between 0.02 and 0.13}

${ }^{2}$ All values are significantly different from zero except those marked (NS) as not significantly different.

${ }^{3} \mathrm{C} 18: 2$ cis- 9, trans- 11 
C14:0 FA (Tables 7 and 8) were positively correlated with FA of the next length of chain (e.g., C6:0 with C8:0, C8:0 with C10.0). The remarkably high correlations found between C8:0, C10:0, and C12:0 (0.59-0.80) might reflect their common biosynthesis origin. These FAs are synthesized de novo in the mammary gland by an elongation process involving 2 enzymes (fatty acid synthase and acetyl CoA carboxylase). When the difference in the length of chain was greater, genetic correlations between SFA tended to be negative. As suggested by Stoop et al. (2008), this might reflect the fact that increased de novo synthesis could convert more short-chain SFA.

The lack of a positive genetic correlation between C16:0 and other SFA might be due to its double origin, because palmitic acid originates partly from mobilization of adipose reserves and is partly synthesized de novo in the mammary gland.

The unsaturated C18 FA (C18:1, C18:2c9t11 or CLA, $\mathrm{n}-3$, and n-6) originate mainly from the diet and are dependent on rumen biohydrogenation and $\Delta^{9}$-desaturase enzymatic activity in the mammary gland (MacGibbon and Taylor, 2006). However, we did not observe strong or consistent genetic correlations between these FA, as reported by Stoop et al. (2008).

Based on these genetic parameters, and as mentioned for heritability, FA could be clustered into 2 groups depending on the metabolic pathway of the lipid synthesis: a first group consisting of individual FA; that is, C6:0 to C16:0, which are synthesized de novo in the mammary gland, and a second group consisting of C18:0 and individual UFA, which are provided directly by the diet and could be transformed slightly by biohydrogenation in the rumen (Polan et al., 1964; Harfoot and Hazlewood, 1988).

Altogether, genetic parameters were similar in both Saanen and Alpine breeds (Tables 6 and 7, Supplemental Tables S1 and S2; http://dx.doi.org/10.3168/jds.20137328). However, genetic correlations of FA expressed in $\mathrm{g} / 100 \mathrm{~g}$ of milk were slightly higher in the Saanen breed. For example, genetic correlations were 0.94 and 0.89 in Saanen compared with 0.89 and 0.69 in Alpine, respectively, between C6:0 and C8:0 and between C14:0 and C16:0. On the contrary, genetic correlations between FA expressed in $\mathrm{g} / 100 \mathrm{~g}$ of milk fat are in the same range for most FA. Consequently, the slight difference found between breeds when FA are explained in milk is not found when FA are explained in fat.

\section{Genetic Correlations of Fat and Protein Contents with Individual FA}

The genetic correlations of FC or SFA with individual SFA C6:0 to C10:0 expressed in $\mathrm{g} / 100 \mathrm{~g}$ of fat were positive (from 0.17 to 0.59 ) in both breeds (Table 7, Supplemental Table S2; http://dx.doi.org/10.3168/ jds.2013-7328). Correlations of SFA or FC with longer chain C12:0 to C16:0 (Table 7, Supplemental Table S2; http://dx.doi.org/10.3168/jds.2013-7328) were generally lower $(-0.35$ to 0.20$)$ and mostly negative with C14:0 ( -0.17 to -0.35$)$. Moreover, in contrast to results in cattle (Soyeurt et al., 2007; Stoop et al., 2008), the genetic relationship of $\mathrm{FC}$ with $\mathrm{C} 16: 0$ was very low $(-0.01$ to 0.15$)$ and that with C18:0 was not significantly different from zero (Table 6, Supplemental Table S1; http://dx.doi.org/10.3168/jds.2013-7328). The values of the genetic correlations between FA and PC were similar (Table 7, Supplemental Table S2; http://dx.doi.org/10.3168/jds.2013-7328), except for a higher positive correlation with $\mathrm{C} 12: 0$ (0.26 to 0.49 ). Given these results, selection on FC and PC is expected to slightly increase the amounts of short-chain SFA (except C4:0) and to reduce or have no effect on the contents of C14:0, C16:0, and C18:0. As C16:0 or C14:0 are generally considered unfavorable FA for human health (Hu et al., 1999; Arnould and Soyeurt, 2009), genetic selection to increase FC and PC should have a beneficial effect by reducing (or limiting the increase in) their relative proportions in fat. Similar trends for C14:0 were reported previously by Soyeurt et al. (2007). In contrast, genetic selection on FC and $\mathrm{PC}$ should incur an increase in specific goat $\mathrm{FA}$, such as caproic (C6:0), caprylic (C8:0), and capric (C10:0) acids.

It is important to note that the genetic parameters estimated here, based on predicted FA, could be validated in the future by increasing the size of the calibration data set. In general, FA or groups of FA with higher contents in milk (C16:0, C18:1, SFA, UFA, MUFA) were predicted accurately enough, as reported in cow (Soyeurt et al., 2011; Maurice-Van Eijndhoven et al., 2013). Small FA, such as C4:0 and to a lesser extent C6:0, also had reasonable accuracies, despite a low content in milk. The relative error of estimation equations, however, was high (14-20\%) for some FA (especially CLA, C12:0; C18:0, n-3 group). This is partly due to lower content and low variability in goat milk (Ferrand et al., 2011). Also, because the calibration set was of limited size (199 Alpine and Saanen goats), it is possible that all biological natural variability of FA in these 2 French breeds has not been captured. Improvement in accuracies of the estimated FA and validation of genetic parameter estimates (especially genetic correlations) could therefore be expected by increasing the calibration set (Rutten et al., 2010). Some FA, however, can be predicted more successfully by MIR spectra than others. For the latter, the increase in accuracy as a consequence of the increase in the number of calibra- 
tion samples is probably limited to a certain threshold (Rutten et al., 2010).

The composition of milk fat is subject to substantial genetic variation, which opens the way to modifying the FA profile by selection. A selection criterion could be the amount of FA in milk fat if the breeding objective were to modify the FA profile toward less long-chain SFA, for instance. Before including the FA content or profile in the breeding objectives, however, further analyses of correlations with other traits already under selection (such as type traits) have to be done. Initial results at least suggest that no deterioration of the FA profile will occur with current selection, unlike in cattle, regarding the specificity of products and human health. Finally, although FA are not the main interest of the goat industry, which is more concerned with protein content, discussions between breeders, farmers, and industry about the willingness to change goat milk FA composition or to develop specific products are ongoing.

\section{CONCLUSIONS}

This study provides the first estimates for the genetic parameters of FA content in goat milk estimated using MIR spectra. Heritability estimates for individual FA, expressed in $\mathrm{g} / 100 \mathrm{~g}$ of milk, ranged from 0.18 to 0.38 , with most values between 0.20 and 0.25 . Heritabilities were even higher when FA were expressed in $\mathrm{g} / 100 \mathrm{~g}$ of fat (average of 0.29), indicating that the composition of milk fat is subject to substantial genetic variation. The genetic correlation between milk production and FA profile was weak. Fat content was positively genetically correlated with SFA and MUFA at the expense of PUFA. The positive association between FC and SFA reflected a positive genetic correlation with mediumchain FA, such as specific goat FA (C6:0 to C10:0), and weak genetic correlations with the FA that are often described as undesirable in excess for human health (C14:0 and C16:0). The values of genetic correlations between PC and individual FA were similar, although genetic correlations between $\mathrm{PC}$ and FA groups (saturated and unsaturated) were close to zero. Because estimation equations for FA were based on a small data set and precision was weak for some FA, however, it will be useful to confirm these results with more accurate predictions. In conclusion, it seems possible to change the FA profile by genetic selection. Increasing PC and FC by the current genetic selection is not expected to have an undesirable effect on the FA profile.

\section{ACKNOWLEDGMENTS}

Cyrielle Maroteau acknowledges the support of the Union Nationale des Cooperatives d'Elevage et
d'Insémination Animale (UNCEIA, Paris, France), APIS GENE (Paris, France) and CAPGENES (Mignaloux-Beauvoir, France) for her scholarship (CIFRE = Conventions Industrielles de Formation par la Recherche). The data used in this study were funded as part of the multispecies French PhénoFinLait program, with the financial contribution of ANR, APIS GENE, CNIEL (Maison du Lait, Paris, France), FranceAgriMer (Montreuil-sous-Bois, France), France Genetique Elevage (Paris, France), and the Ministry of Agriculture (Paris, France). We thank all the people involved in collecting and processing the data: breeders, laboratories, milk recording agency, Jean Legarto (Institut de l'Elevage, Castanet-Tolosan, France), and Hugues Caillat (INRA, Toulouse, France). The authors thank Felicie Lahalle and Mickaël Brochard (both of Institut de l'Elevage, Paris, France) for their help reviewing the manuscript.

\section{REFERENCES}

Arnould, V. M., and H. Soyeurt. 2009. Genetic variability of milk fatty acids. J. Appl. Genet. 50:29-39.

Belichon, S., E. Manfredi, and A. Piacere. 1999. Genetic parameters of dairy traits in the Alpine and Saanen goat breeds. Genet. Sel. Evol. 30:529-534.

Bobe, G., J. A. Minick Bormann, G. L. Lindberg, A. E. Freeman, and D. C. Beitz. 2008. Short communication: Estimates of genetic variation of milk fatty acids in us Holstein cows. J. Dairy Sci. 91:1209-1213.

Breznik, S., A. Malovrh, M. Kovac, D. Birtic, and D. Kompan. 2000. Additive genetic and environmental variance components for milk traits in goat with test day model. Zootecnika 76:61-67.

Brochard, M., F. Faucon, F. Barillet, M. Bolard, P. Brunschwig, K. Duhem, A. Eggen, S. Esvan, M. Ferrand, S. Fritz, P. L. Gastinel, J. L. Guerin, L. Journaux, T. Krychowski, G. Lagriffoul, H. Larroque, C. Lecomte, O. Leray, C. Leroux, C. Leverrier, P. Martin, S. Mattalia, G. Miranda, I. Palhiere, J. L. Peyraud, and D. Boichard. 2009. PhenoFinLait: A French national project to detect QTL or major genes affecting the fine composition of dairy ruminants' milk. Page 423 in Proc. 16th Rencontres Recherches Ruminants. INRA and Institut de l'Elevage, Paris, France.

Chilliard, Y., and A. Ferlay. 2004. Dietary lipids and forages interactions on cow and goat milk fatty acid composition and sensory. Reprod. Nutr. Dev. 44:467-492.

Chilliard, Y., A. Ferlay, and M. Doreau. 2001. Contrôle de la qualité nutritionnelle des matières grasses du lait par l'alimentation des vaches laitières: Acides gras trans, polyinsaturés, acide linoléique conjugué. INRA Prod. Anim 14:323-335.

Chilliard, Y., A. Ferlay, J. Loor, J. Rouel, and B. Martin. 2002. Trans and conjugated fatty acids in milk from cows and goats consuming pasture or receiving vegetable oils or seeds. Ital. J. Anim. Sci. $1: 243-254$

Chilliard, Y., A. Ferlay, J. Rouel, and G. Lamberet. 2003. A review of nutritional and physiological factors affecting goat milk lipid synthesis and lipolysis. J. Dairy Sci. 86:1751-1770.

Chilliard, Y., F. Glasser, F. Enjalbert, A. Ferlay, and P. Schmidely. 2008. Recent data on the effects of feeding factors on cow milk fatty acid composition. Sci. Aliments 28:156-167.

Chilliard, Y., J. Rouel, and C. Leroux. 2006. Goat's alpha-s1 casein genotype influences its milk fatty acid composition and delta-9 desaturation ratios. Anim. Feed Sci. Technol. 131:474-487.

Clement, V., D. Boichard, A. Piacère, A. Barbat, and E. Manfredi. 2002. Genetic evaluation of French goats for dairy and type traits. Page 235-238 in Proc. 7th World Congr. Genet. Appl. Livest. Prod. INRA, Castanet-Tolosan, France. 
Ferrand, M., B. Huquet, F. Bouvier, H. Caillat, F. Barillet, F. Faucon-Lahalle, H. Larroque, O. Leray, I. Palhiere, and M. Brochard. 2011. Use of genetic algorithm on mid-infrared spectrometric data: Application to estimate the fatty acids profile of goat milk. J. App. Stat. Anal. 4:245-254.

Ferrand-Calmels, M., I. Palhière, M. Brochard, O. Leray, J. M. Astruc, M. R. Aurel, S. Barbey, F. Bouvier, P. Brunschwig, H. Caillat, M. Douguet, F. Faucon-Lahalle, M. Gelé, G. Thomas, J. M. Trommenschlager, and H. Larroque. 2014. Prediction of fatty acid profiles in cow, ewe, and goat milk by mid-infrared spectrometry. J. Dairy Sci. 97:17-35.

Gion, A., H. Larroque, M. Brochard, F. Lahalle, and D. Boichard. 2011. Genetic parameter estimation for milk fatty acids in three French dairy cattle breeds. Interbull Bull. 44:185-189.

Haenlein, G. F. W. 2004. Goat milk in human nutrition. Small Rumin. Res. 51:155-163.

Harfoot, C. G., and G. P. Hazlewood. 1988. Lipid metabolism in the rumen. Pages 382-426 in The Rumen Microbial Ecosystem. P. N. Hobson and C. S. Stewart, ed. Springer, Amsterdam, the Netherlands.

Haug, A., A. T. Hostmark, and O. M. Harstad. 2007. Bovine milk in human nutrition-A review. Lipids Health Dis. 6:25.

Hu, F. B., M. J. Stampfer, J. A. E. Manson, A. Ascherio, G. A. Colditz, F. E. Speizer, C. H. Hennekens, and W. C. Willett. 1999. Dietary saturated fats and their food sources in relation to the risk of coronary heart disease in women. Am. J. Clin. Nutr. 70:1001-1008.

Institut de l'Élevage. 2010. Les chiffres clés 2010: Productions caprines lait and viande. Institut de l'Elevage, Paris, France.

Karijord, A., N. Standal, and O. Syrstad. 1982. Sources of variation in composition of milk fat. Z. Tierzuecht. Zuechtungsbiol. 99:81-93.

MacGibbon, A. K. H., and M. W. Taylor. 2006. Composition and structure of bovine milk lipids. Pages 1-42 in Advanced Dairy Chemistry, Volume 2, Lipids. P. F. Fox and P. L. H. McSweeney, ed. Springer, New York. NY.

Martin, P. 2008. La génétique, source de variabilité et d'adaptabilité de la matière grasse laitière. Sci. Aliments 28:168-175.

Maurice-Van Eijndhoven, M. H. T., H. Soyeurt, F. Dehareng, and M. P. L. Calus. 2013. Validation of fatty acid predictions in milk using mid-infrared spectrometry across cattle breeds. Animal 7:348-354

Mele, M., R. Dal Zotto, M. Cassandro, G. Conte, A. Serra, A. Buccioni, G. Bittante, and P. Secchiari. 2009. Genetic parameters for conjugated linoleic acid, selected milk fatty acids, and milk fatty acid unsaturation of Italian Holstein-Friesian cows. J. Dairy Sci. 92:392-400.

Mensink, R. P., P. L. Zock, A. D. M. Kester, and M. B. Katan. 2003 Effects of dietary fatty acids and carbohydrates on the ratio of serum total to HDL cholesterol and on serum lipids and apolipoproteins: A meta-analysis of 60 controlled trials. Am. J. Clin. Nutr. $77: 1146-1155$

Meyer, K. 2007. WOMBAT: A tool for mixed model analyses in quantitative genetics by REML. J. Zhejiang Univ. Sci. B 8:815-821.

Ollier, S., C. Leroux, A. De la Foye, L. Bernard, J. Rouel, and Y. Chilliard. 2009. Whole intact rapeseeds or sunflower oil in high- forage or high-concentrate diets affects milk yield, milk composition, and mammary gene expression profile in goats. J. Dairy Sci. 92:5544-5560.

Polan, C. E., J. J. McNeill, and S. B. Tove. 1964. Biohydrogenation of unsaturated fatty acids by rumen bacteria. J. Bacteriol. 88:10561064 .

Raynal-Ljutovac, K., G. Lagriffoul, P. Paccard, I. Guillet, and Y. Chilliard. 2008. Composition of goat and sheep milk products: An update. Small Rumin. Res. 79:57-72.

Renner, E., and U. Kosmack. 1974. Genetische Aspekte zur Fettsäurenzusammensetzung des Milchfettes. 2. Fettsäurenmuster der Milch von Nachkommenpopulationen. Zuchtungskunde 46:217-226.

Rupp, R., V. Clément, A. Piacere, C. Robert-Granié, and E. Manfredi. 2011. Genetic parameters for milk somatic cell score and relationship with production and udder type traits in dairy Alpine and Saanen primiparous goats. J. Dairy Sci. 94:3629-3634.

Rutten, M. J. M., H. Bovenhuis, and J. A. M. van Arendonk. 2010. The effect of the number of observations used for Fourier transform infrared model calibration for bovine milk fat composition on the estimated genetic parameters of the predicted data. J. Dairy Sci. 93:4872-4882.

Sanchez, J. P., F. San Primitivo, E. Barbosa, L. Varona, and L. F. De La Fuente. 2010. Genetic determination of fatty acid composition in Spanish Churra sheep milk. J. Dairy Sci. 93:330-339.

SAS Institute. 2008. SAS User's Guide. SAS Institute Inc., Cary, NC.

Schaeffer, L. R., and B. P. Sullivan. 1994. Genetic evaluation of dairy goats using test day yields. Page 182 in Proc. 5th World Congr. Genet. Appl. Livest. Prod., Guelph, Ontario, Canada. University of Guelph, Guelph, ON, Canada.

Skjevdal, T. 1979. Flavour of goat's milk: A review of studies on the sources of its variations. Livest. Prod. Sci. 6:397-405.

Soyeurt, H., P. Dardenne, F. Dehareng, G. Lognay, D. Veselko, M. Marlier, C. Bertozzi, P. Mayeres, and N. Gengler. 2006a. Estimating fatty acid content in cow milk using mid-infrared spectrometry. J. Dairy Sci. 89:3690-3695.

Soyeurt, H., P. Dardenne, A. Gillon, C. Croquet, S. Vanderick, P. Mayeres, C. Bertozzi, and N. Gengler. 2006b. Variation in fatty acid contents of milk and milk fat within and across breeds. J. Dairy Sci. 89:4858-4865.

Soyeurt, H., F. Dehareng, N. Gengler, S. McParland, E. Wall, D. P. Berry, M. Coffey, and P. Dardenne. 2011. Mid-infrared prediction of bovine milk fatty acids across multiple breeds, production systems, and countries. J. Dairy Sci. 94:1657-1667.

Soyeurt, H., and N. Gengler. 2008. Genetic variability of fatty acids in bovine milk. Biotechnol. Agron. Soc. Environ. 12:203-210.

Soyeurt, H., A. Gillon, S. Vanderick, P. Mayeres, C. Bertozzi, and N. Gengler. 2007. Estimation of heritability and genetic correlations for the major fatty acids in bovine milk. J. Dairy Sci. 90:44354442 .

Stoop, W. M., J. A. M. Van Arendonk, J. M. L. Heck, H. J. F. Van Valenberg, and H. Bovenhuis. 2008. Genetic parameters for major milk fatty acids and milk production traits of Dutch HolsteinFriesians. J. Dairy Sci. 91:385-394. 